\title{
SOME OBSERVATIONS ON COPRA DRYING IN SRI LANKA
}

\author{
M C P Rodrigo, B L Amarasiriwardene' and U Samarajeewa \\ Department of Food Science and Technology, \\ University of Peradeniya, Peradeniya, Sri Lanka
}

\begin{abstract}
Twenty five commercial copra kilns in Sri Lanka were studied for variations of their dimensions and copra curing practices in relation to the "Standard Ceylon Copra Kiln" and the quality of copra produced. Changes in the height and the width of the platform resulting in probable changes in drying conditions of copra was noted. The use of powdered charcoal appeared to improve the quality of copra produced and more cost effective than use of coconut shells. Addition of sulphur dust to the fuel further improved the quality of copra.
\end{abstract}

\section{INTRODUCTION}

Extraction of coconut oil by converting the coconut kernels to copra continues to be the most economical and efficient method in spite of several disadvantages (Samarajeewa, 1993). The production of copra is labour intensive, results in under dried and over dried kemels at times, uses most of the valuable coconut shells as fuel, and also results in deposition of polycyclic aromatic hydrocarbons (PAH) on the surface of kernels. Some of the PAH are carcinogenic and pass into. edible oils on extraction (Wijeratne et al., 1996).

The kilns used to dry coconut kernels vary from country to country in the SouthEast Asian region (Timmins, 1995). The capacity, the methods of operation, the fuel used and the quality of coconut kernels used depends on the types of drying processes although they all basically operates on the direct drying principles. The quality of the copra produced varies widely depending on the types and operational conditions of the kilns. Some of the existing kilns (dryers) and the operational conditions are reviewed by Patel (1985).

In Sri Lanka, coconut kemels were dried using the "Chula dryer" introduced in 1923 for copra manufacture. The "Chula dryer" operates on indirectly heated air generated by a furnace. This dryer was replaced by the direct air heated "Standard Ceylon Copra Kiln" (STD) designed in 1960s. This model is still considered to be the most economical and drying is practiced following the guidelines stipulated with

1 Coconut Development Authority, Colombo, Sri Lanka. 
the design of the kiln (The Ceylon Copra Kiln, 1965). The drying operation reduces the moisture content in the kernels from 43\% to 8\% (Nathanael, 1962). However, the design of the kiln and the drying procedure has got modified over the years in the hands of the copra manufactures. A study of 25 copra kilns was carried out to understand the modifications and the resulting effects on copra quality processed in the present kilns. Currently there is a need to improve the copra production methods to meet the demand for a quality copra - white in appearance and containing no smoke deposits, thus avoiding PAH.

\section{MATERIALS AND METHODS}

Twenty five copra kilns in the Marawila-Chilaw area were visited. The measurements of the copra kilns and the copra drying chambers were made. The method of copra drying in relation to the type of fuel used (coconut shells, coconut charcoal; other) the pattern of spread of the fuel on the surface (number and spacing of rows or other spreads) were examined. A breakdown of the quality of copra based on the commercial grading system (white edible, edible, milling superior, milling ordinary) was carried out in relation to each of the mills.

\section{RESULTS AND DISCUSSION}

\section{General Information}

The general information on the over all dimensions of the copra kilns, the locations of the ventilation openings in the firing chamber and the operational procedure practiced in copra drying are summarized in the tables 1 to 3 respectively. All parameters show a wide range of variation compared to the kiln at the Coconut Research Institute. With regard to the over all size of the kilns there are differences between the "Standard Ceylon Copra Kiln" (STD) described in the advisory leaflet and the one used at the Coconut Research Institute (CRI) too. The mean dimensions of the kilns in the field lie between that of the CRI and STD kilns.

Of the different parameters, the width of the drying chamber and the distance between the floor and the drying platform are critical in the drying process. The mean width of the platform in commercial mills is $2.8 \pm 1.2 \mathrm{~m}$ as against the widths of 1.1 and $1.5 \mathrm{~m}$ recommended and used in the STD and CRI kilns (Table 1). To compensate for the doubling in the width in commercial mills the copra producers lay two or more rows of shells to be burned instead of a single row recommended (Table 3). The variations in gaps between the rows of shells laid down in the different kilns and the number of lines of shells per row can result in overlap of heat cones and heat intensities or unheated gaps at the drying platform leading to uneven drying of copra.

Most kilns operate with a much lower height (mean $2 \pm 0.4) \mathrm{m}$ as against $3 \mathrm{~m}$ 
recommended in the STD kiln and $2.4 \mathrm{~m}$ used in CRI kiln (Table 1). The heights of the drying chambers are reduced, perhaps with the intention of catching the heat early, thus economizing on the fuel. However, it is not known whether the reduced height results in increased scorching of copra or the burning is adjusted in such a way to overcome possible scorching. The combination of wider platform and reduced height in the drying chamber would certainly affect the quality of copra.

\section{Overlap of Heat Cones}

It is assumed that the design of the "Standard Ceylon Copra Kiln" and construction of the CRI kiln have taken into consideration the most efficient heat distribution in each chamber. On the basis of the design of the drying chambers of CRI and STD kilns, one could assume the presence of an inverted heat cone with apex at the burning point of shells and base overlapping with the surface of platform containing copra to be dried. The angle at the apex of the inverted cone works out to be $26^{\circ}$ and $28^{\circ}$ for the CRI and STD kilns.

When the concept of heat cone is extended to the commercial kilns examined, the drying appears to occur with overlapping of the base of heat cones in most of the kilns, sometimes resulting in $100 \%$ overlap on the basis of the diameter of the cone (Table 4). In situations with $30 \%$ to $50 \%$ overlap one could expect areas of higher temperatures and increased rates of drying. The high temperature areas on the drying platform may. result in case hardened and scorched copra. On the other hand if the rows of shells are too far apart leaving unheated or low temperature areas outside the heat cones during drying, copra may become slimy due to bacterial growth on the surface. It is important to adhere to stipulated dimensions in the drying chamber and laying of the rows of fuel for uniform and efficient drying. The temperatures of the kernels at drying need to be monitored to understand the performance of the modified commercial mills. An examination of the percent distribution of under-dried or over-dried copra produced in the modified kilns may provide necessary information for required adjustments.

\section{Ventilation}

In addition to the door which allows entry of plenty of air during burning of shells, windows are kept for ventilation in most of the kilns in keeping with the requirements laid down in the CRI leaflet (Table 2). During drying of copra the door is normally kept closed for controlled burning of shells.

The ratio of total volume of the copra drying chamber to the area of the ventilation openings (window or the window and the door together) varied widely, in the commercial kilns showing a very high standard deviation (Table 5). It is not known whether such variations do effect the quality of copra. The possible effects are worth examining. 


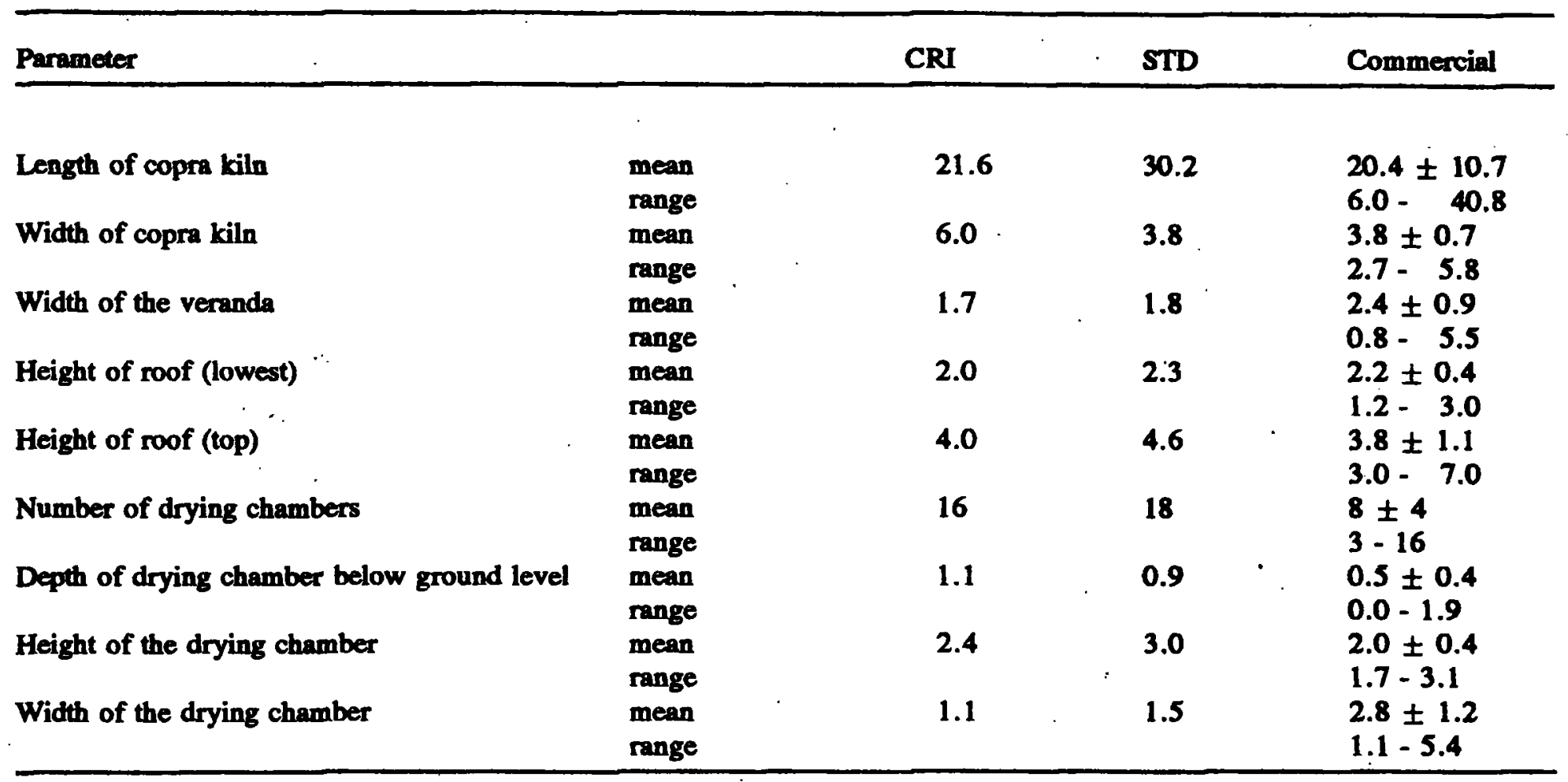

CRI - Copra kiln used in the Coconut Research Institute

STD - 'Standard Copra Kiln' recommended in the CRI Leaflet No. 15. 
Table 2. Location of ventilation openings in copra kiln.

\begin{tabular}{|c|c|c|c|c|}
\hline Parameter & & CRI & STD & Commercial \\
\hline Windows per chamber & $\begin{array}{l}\text { mean } \\
\text { range }\end{array}$ & 1 & 1 & $\begin{array}{l}2 \pm 0.6 \\
0-6\end{array}$ \\
\hline Distance between two windows & $\begin{array}{l}\text { mean } \\
\text { range }\end{array}$ & n.a. & n.a. & $\begin{array}{l}0.5 \pm 0.6 \\
0-2.1\end{array}$ \\
\hline Height of window from floor & $\begin{array}{l}\text { mean } \\
\text { range }\end{array}$ & 1.2 & 0.3 & $\begin{array}{l}0.6 \pm 0.5 \\
0.1-1.4\end{array}$ \\
\hline Distance of window from the wall & $\begin{array}{l}\text { mean } \\
\text { range }\end{array}$ & 0.5 & 0.7 . & $\begin{array}{l}0.5 \pm 0.3 \\
0.1-1.1\end{array}$ \\
\hline Width of window & $\begin{array}{l}\text { mean } \\
\text { range }\end{array}$ & 0.1 & 0.2 & $\begin{array}{l}0.1 \pm 0.1 \\
0.1-0.3\end{array}$ \\
\hline Height of window & $\begin{array}{l}\text { mean } \\
\text { range }\end{array}$ & 0.4 & 0.6 & $\begin{array}{l}0.2 \pm 0.2 \\
0.1-0.6\end{array}$ \\
\hline Height of the door & $\begin{array}{l}\text { mean } \\
\text { range }\end{array}$ & 0.8 & 1.2 & $\begin{array}{l}0.8 \pm 0.1 \\
0.6-1.2\end{array}$ \\
\hline Width of the door & $\begin{array}{l}\text { mean } \\
\text { range }\end{array}$ & 0.8 & 0.8 & $\begin{array}{l}1.1 \pm 0.2 \\
0.7-1.6\end{array}$ \\
\hline
\end{tabular}

CRI - Copra kiln used in the Coconut Research Institute

STD - 'Standard Ceylon Copra Kiln' recommended in the CRI Leaflet No. 15.

n.a.- not applicable 


\begin{tabular}{|c|c|c|c|c|}
\hline Parameter & & CRI & STD & Commercial \\
\hline Sun drying & & + & + & $\begin{array}{l}+ \text { in } 22 \\
- \text { in } 3\end{array}$ \\
\hline Fuel & & shell & shell & $\begin{array}{l}\text { shell in } 18 \\
\text { shell }+S \text { in } 1 \\
\text { char in } 2 \\
\text { char }+S \text { in } 4\end{array}$ \\
\hline Number of firings & $\begin{array}{l}\text { mean } \\
\text { range }\end{array}$ & 8 & 8 & $\begin{array}{l}5 \pm 1 \\
2-8\end{array}$ \\
\hline Number of double rows & $\begin{array}{l}\text { mean } \\
\text { range }\end{array}$ & 1 & 2 & $\begin{array}{l}3 \pm 1 \\
1-8\end{array}$ \\
\hline Width of a row & $\begin{array}{l}\text { mean } \\
\text { range }\end{array}$ & 0.4 & n.a. & $\begin{array}{l}0.3 \pm 0.1 \\
0.3-0.4\end{array}$ \\
\hline Distance between rows & $\begin{array}{l}\text { mean } \\
\text { range }\end{array}$ & $\begin{array}{l}\text { n.a. } \\
\text { n.a. }\end{array}$ & $\begin{array}{l}\text { n.a. } \\
\text { n.a. }\end{array}$ & $\begin{array}{l}0.8 \pm 0.9 \\
0.3-1\end{array}$ \\
\hline
\end{tabular}

$\begin{array}{lll}\text { CRI } & - & \text { Copra kiln used in the Coconut Research Institute } \\ \text { STD } & - & \text { 'Standard Ceylon Copra Kiln' recommended in the CRI leaflet No. } 15 \\ \text { char } & - & \text { charcoal powder } \\ \text { S } & - & \text { sulphur powder } \\ + & - & \text { sundried prior to drying in the kiln } \\ - & - & \text { directly kiln dried (no sundrying) } \\ \text { n.a. } & - & \text { not applicable }\end{array}$


Table 4.

Overlap of heat cone during drying of copra in the individual drying chambers of the kilns.

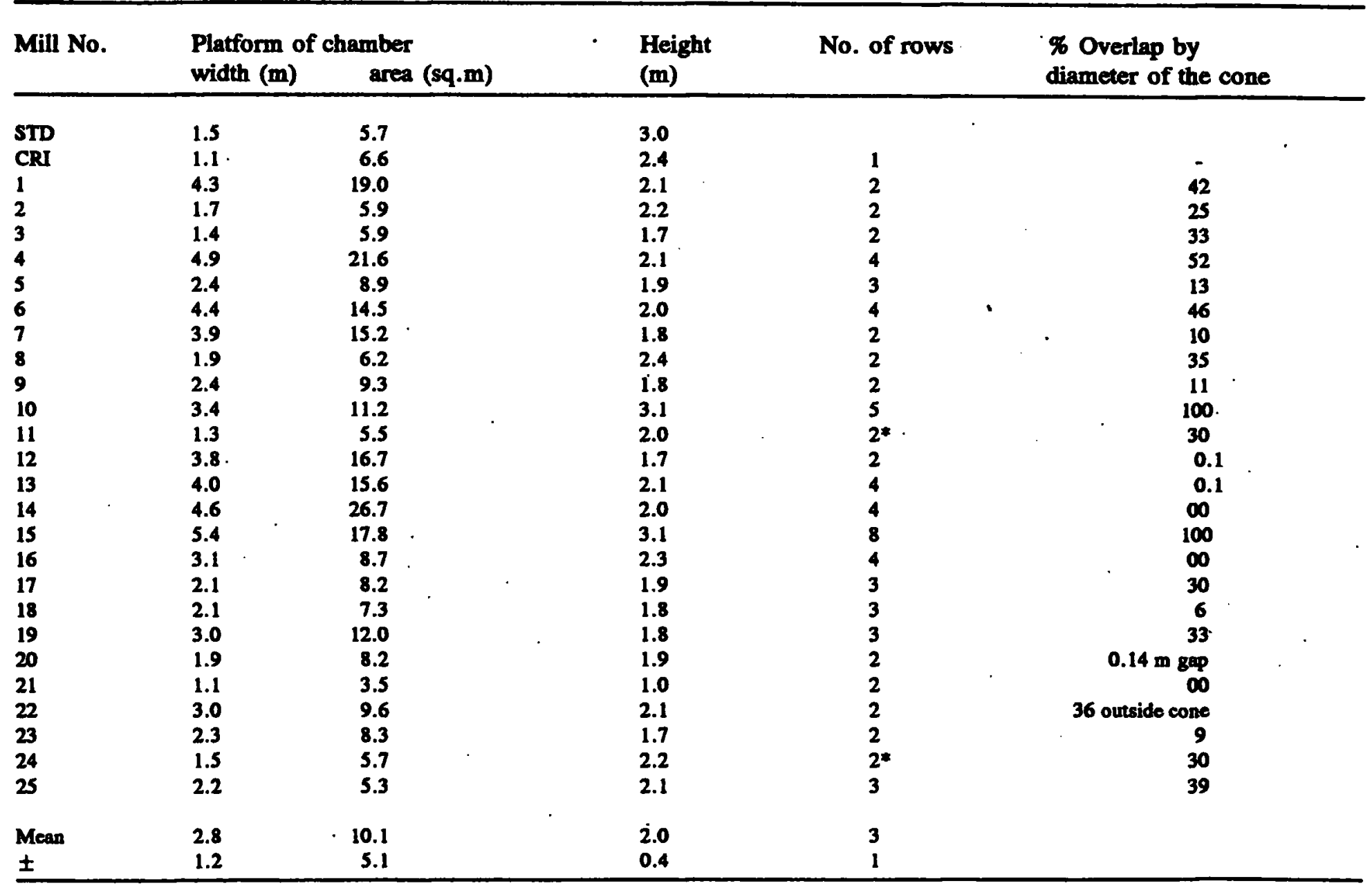

* - Triple rows 
Table 5.

The ventilation cavities of the chamber in relation to total area/wolume of drying chamber.

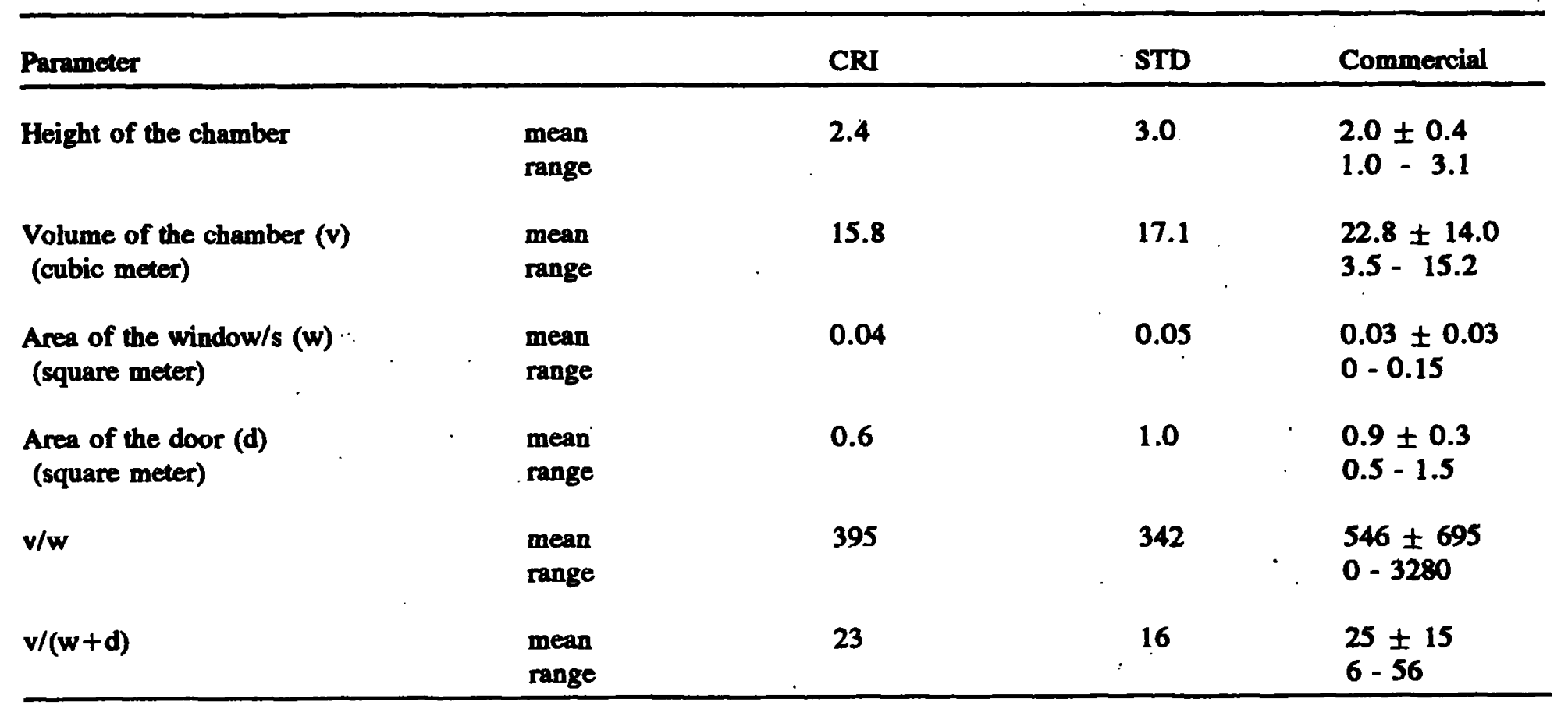

CRI - Copra kiln used in the Coconut Research Institute

STD - 'Standard Ceylon Copra Kiln' recommended in the CRI Leaflet No. 15. 
Table 6. Quality of copra in relation to the fuel used.

Fuel Mill No. $\quad$ Grade of copra

Coconut shells

\begin{tabular}{|c|c|c|}
\hline 1 & & MO $4 \& 5$ \\
\hline 2 & & MO $4 \& 5$ \\
\hline 3 & & MS $1 \& 2$, MO $4 \& 5$ \\
\hline 5 & & MO $4 \& 5$ \\
\hline 7 & . & MO $4 \& 5$ \\
\hline 8 & & MO $4 \& 5$ \\
\hline 9 & & MO $4 \& 5$ \\
\hline 11. & & MO $4 \& 5$ \\
\hline 12 & & MO $4 \& 5$ \\
\hline 13 & & MO 1 \\
\hline 15 & & MS $1,2 \& 3$, MO $4 \& 5$ \\
\hline 16 & & MO $1 \& 2$ \\
\hline 17 & & MS 2, MO \\
\hline 18 & & MS 2, MO \\
\hline 19 & & MS 2, MO 1 \\
\hline 24 & & MS 3, MO $1 \& 2$ \\
\hline 25 & & MO $4 \& 5$ \\
\hline
\end{tabular}

Coconut shells and Sulphur dust .

$\begin{array}{ll}14 & \text { MS } 1 \& 2, \text { MO } \\ 23 & \text { MS } 1 \& 2\end{array}$

Charcoal and Sulphur dust

$\begin{aligned} 4 & \text { MS 1, MS 2 } \\ 6 & \text { Edible, MS 1 \& } 2 \\ 10 & \text { MS 1 \& 2 } \\ 20 & \text { Edible, MS 1 } \\ 21 & \text { Edible, MS 1, MS 2 } \\ 22 & \text { MO 1-5 (only for oil) }\end{aligned}$

The presence of wide openings above the drying platform is necessary to allow outward flow of moist hot air. If the moist air is not removed the moisture tend to condense on the roof and drop back on copra. In six of the kilns observed there was no open walls to allow a cross wind above the drying platform. Two kilns contained only windows for air movement, which may be inadequate. 


\section{Fuel Used}

There are two types of fuel used in the copra kilns. While most of the kilns use shells as fuel, a few use charcoal. Addition of sulphur dust to the fuel is also becoming popular (Table 6). Judging by the over all grades of copra produced as determined by an expert on quality, the use of charcoal provides a distinctly improved quality in copra (MS and edible grades) and the use of sulphur dust (100 g per row) produces a white copra which could fetch better prices in the market. The use of sulphur is probably not objectionable as sulphur dioxide is commonly used in fumigating the ship on carrying copra in bulk (Salunke et al., 1992).

The use of charcoal is coupled with certain advantageous modificaitons of the drying practices and cost effects. The charcoal dust. used is a low cost fuel (Rs. 1500/-per ton) compared to the shells. It appears that one could increase the profit margin by converting the shells to high value charcoal and using the residual charcoal powder as a fuel. The copra producers using charcoal as fuel have also done away with initial sun-drying of kernels, but have introduced selection of only well matured kernels and arranging the kernel cups inverted on the drying platform.

\section{CONCLUSION}

It is important to investigate further, the effect of different layouts of shells for burning on the percent distribution of quality and moisture content of the copra. Since the use of charcoal and sulphur appears to carry a distinct advantage in relation to quality, shifting of the present drying method to use of charcoal powder may be worth giving consideration.

\section{ACKNOWLEDGEMENT}

The authors thank the Coconut Development Authority, the Coconut Research Institute of Sri Lanka and the copra manufacturers for assistance in this study.

\section{REFERENCES}

Nathanael, W R N (1962) Report of the chemist, Ceylon Cocon. Q., 14: (1/2) 21-24.

Patel, R T (1985) Copra drying process and equipments. J. Plant. Crops, 13: (2) 78-87.

Rodrigo, M C P and Samarajeewa, U (1995) Production and utilization of coconut kernel products in Sri Lanka. Proceedings of the European Community Project Seminar on polyaromatic hydrocarbons in copra and derived products, 24-26 July, 1995, Bogor, Indonesia. 
Salunke, D K, Chavan, J K, Adsalf, R H and Kadam, S S (1992) World Oil Seeds: Chemistry, technology and utilization. AVI, Van Nostrand Reinho, New York.

Samarajeewa, U (1993) Improvements in coconut processing in the South-East Asia. Proceedings of the Third International Food Convention. 7-12 September, 1993. Mysore, India, pp. 166.

The Ceylon Copra kiln (1965) Coconut Research Institute Leaflet No. 15.

Timmins, W H (1994) Polycyclic aromatic hydrocarbons and copra. Proceedings of the European Community Project Seminar on Polyaromatic Hydrocarbons in Copra and Derived Products. 24-26 July, 1995, Bogor, Indonesia.

Wijeratne, M C P, Samarajeewa, U and Rodrigo, M C P (1996) Polycyclic aromatic hydrocarbons in coconut kernel products. J. Nat. Sci. Council of Sri Lanka. (in press) 